\title{
$\mu$-Opioid Receptor Trafficking on Inhibitory Synapses in the Rat Brainstem
}

\author{
Kirsteen N. Browning, ${ }^{1}$ Alexander E. Kalyuzhny, ${ }^{3}$ and R. Alberto Travagli ${ }^{1,2}$ \\ Departments of ${ }^{1}$ Internal Medicine-Gastroenterology and ${ }^{2}$ Physiology, University of Michigan Medical Center, Ann Arbor, Michigan 48109, and \\ ${ }^{3}$ Department of Neuroscience, University of Minnesota, Minneapolis, Minnesota 55455
}

Whole-cell recordings were made from identified gastric-projecting rat dorsal motor nucleus of the vagus (DMV) neurons. The amplitude of evoked IPSCs (eIPSCs) was unaffected by perfusion with met-enkephalin (ME) or by $\mu$-, $\delta$-, or $\kappa$-opioid receptor selective agonists, namely D-Ala ${ }^{2}-N$-Me-Phe ${ }^{4}$-Glycol ${ }^{5}$-enkephalin (DAMGO), cyclic [D-Pen ${ }^{2}$-D-Pen ${ }^{5}$-enkephalin, or trans-3,4-dichloro- $N$-methyl- $N$-[2-(1pyrolytinil)-cyclohexyl]-benzeneacetamide methane sulfonate (U50,488), respectively. Brief incubation with the adenylate cyclase activator forskolin or the nonhydrolysable cAMP analog 8-bromo-cAMP, thyrotropin releasing hormone, or cholecystokinin revealed the ability of ME and DAMGO to inhibit IPSC amplitude; this inhibition was prevented by pretreatment with the $\mu$-opioid receptor (MOR1) selective antagonist D-Phe-Cys-Tyr-D-Trp-Orn-Thr-Pen-Thr- $\mathrm{NH}_{2}$. Conversely, incubation with the adenylate cyclase inhibitor dideoxyadenosine, with the protein kinase A (PKA) inhibitor $\mathrm{N}$-[2-( $p$-Bromocinnamyl-amino)ethyl]-5-isoquinolinesulfonamide dihydrochloride (H89), or with the Golgi-disturbing agent brefeldin A, blocked the ability of forskolin to facilitate the inhibitory actions of ME. Immunocytochemical experiments revealed that under control conditions, MOR1 immunoreactivity (MOR1-IR) was colocalized with glutamic acid decarboxylase (GAD)-IR in profiles apposing DMV neurons only after stimulation of the cAMP-PKA pathway. Pretreatment with $\mathrm{H} 89$ or brefeldin A or incubation at $4^{\circ} \mathrm{C}$ prevented the forskolin-mediated insertion of MOR1 on GAD-IR-positive profiles.

These results suggest that the CAMP-PKA pathway regulates trafficking of $\mu$-opioid receptors into the cell surface of GABAergic nerve terminals. By consequence, the inhibitory actions of opioid peptides in the dorsal vagal complex may depend on the state of activation of brainstem vagal circuits.

Key words: autonomic; brainstem; gastrointestinal; opioid; vagus

\section{Introduction}

Within the rat dorsal vagal complex (DVC) [i.e., the nucleus of the tractus solitarius (NTS) and the dorsal motor nucleus of the vagus (DMV)], the NTS provides a predominantly GABAergic input to the DMV, which in turn exerts a tonic inhibition of excitatory cholinergic pathways targeting the gastrointestinal tract (Travagli and Rogers, 2001). A robust glutamate innervation is also present in the NTS-DMV synapse (Travagli and Rogers, 2001), although it does not seem to be tonically active. Many neurotransmitters, including opioids, interact with presynaptic receptors to modulate synaptic activity. Our previous electrophysiological and immunohistochemical studies have shown that opioid peptides inhibit excitatory glutamatergic but not inhibi-

\footnotetext{
Received May 3, 2004; revised July 6, 2004; accepted July 8, 2004.

This work was supported by National Institutes of Health Grant DK55530. We thank Dr. R. Elde (University of Minnesota, Minneapolis, MN) for providing MOR1 antiserum, Galina Kalyuzhnaya for technical assistance in the immunohistochemical experiment, and Dr. R. C. Rogers for comments on previous versions of this manuscript. We also thank Cesare M. Travagli for support and encouragement.

Correspondence should be addressed to Dr. R. Alberto Travagli, Neuroscience, Pennington Biomedical Research Center, Louisiana State University System, 6400 Perkins Road, Baton Rouge, LA 70808. E-mail: alberto.travagli@pbrc.edu.

K. N. Browning's present address: Neuroscience, Pennington Biomedical Research Center, Louisiana State University, 6400 Perkins Road, Baton Rouge, LA 70808.

DOI:10.1523/JNEUROSCI.1676-04.2004

Copyright $\odot 2004$ Society for Neuroscience $\quad$ 0270-6474/04/247344-09\$15.00/0
}

tory GABAergic synaptic transmission via actions at presynaptic $\mu$-opioid receptors within the rat DVC (Browning et al., 2002).

Anatomical studies have shown that presynaptic opioid receptors might be associated with dense-core vesicles, where the $\alpha$ subunits of G-proteins might also be localized (Aronin and DiFiglia, 1992; Cheng et al., 1995; Drake et al., 1996; Zhang et al., 1998; Shuster et al., 1999; Commons et al., 2000; Commons, 2003). This type of association raises the possibility that G-protein-mediated activity may modulate receptor functions. In fact, cAMP-dependent membrane protein trafficking has been reported in several systems. Hormone-dependent activation induces the insertion of several membrane proteins into different neuronal and non-neuronal cell types (Cushmann and Wardzala, 1980; Lewis and de Moura, 1984; Kim and Von Zastrow, 2003), whereas elevations in cAMP levels stimulate the rapid translocation of the neurotrophin receptor tyrosine receptor kinase $\mathrm{B}$ (TrkB) into the cell membrane of central neurons (Meyer-Franke et al., 1998). Indeed, it is possible that second messenger-induced insertion of receptors into nerve terminal membranes may be a more generalized means by which neurotransmitter release can be regulated at the level of the presynaptic nerve terminal. Our previous studies in the rat brainstem have demonstrated a large degree of plasticity in the modulation of GABAergic synaptic transmission (Browning and Travagli, 2001). Specifically, activation of the CAMP-protein kinase A (PKA) pathway increases the 
number of GABAergic synapses undergoing modulation by presynaptic $5-\mathrm{HT}_{1 \mathrm{~A}}$ receptors. The comparatively rapid time course of this response argues against a cAMP-dependent transcriptional or translational increase in receptor number but, rather, implies a rapid second messenger-dependent mechanism, possibly involving the insertion of receptors into the cell membrane.

Recent anatomical studies have shown stimulus-dependent translocation of $\kappa$ - and $\delta$-opioid receptors to the plasma membrane in both posterior pituitary and periaqueductal gray neurons (Shuster et al., 1999; Commons, 2003). To our knowledge, however, trafficking and insertion of $\mu$-opioid receptors has not yet been reported.

The aims of this study were to determine whether the activity of the CAMP-PKA pathway regulates the insertion of opioid receptors on GABAergic nerve terminals apposing identified gastrointestinal parasympathetic motoneurons and, if so, to determine the mechanism of receptor trafficking. Preliminary accounts of this work have been presented in abstract form (Browning et al., 2003).

\section{Materials and Methods}

Retrograde tracing. The neuronal tracer $1,1^{\prime}$-dioctadecyl-3,3,3',3'tetramethylindocarbocyanine perchlorate $\left(\mathrm{DiIC}_{18}(3)\right.$; DiI) was used to label gastric-projecting neurons of the DMV as described previously (Browning et al., 1999). Briefly, 14-d-old rat pups of either sex were anesthetized deeply with halothane (abolition of the foot-pinch withdrawal reflex) before the head of the rat was placed in a custom-made anesthetic chamber through which halothane mixed with air was pumped $(400-600 \mathrm{ml} / \mathrm{min})$, in accordance with veterinary guidelines. The abdominal area was shaved and cleaned with an aqueous iodine solution before performing an abdominal laparotomy. DiI crystals were applied to one gastric region per rat (either the major curvature of the fundus or corpus or the antrum-pylorus). The crystals were embedded to the application site using a fast-settling epoxy compound that was allowed to harden for several minutes before the entire surgical area was washed with warm sterile saline. The laparotomy was closed with 5/0 suture, and the animal was allowed to recover for 10-15 d.

Electrophysiological recording. Thin brainstem slices were prepared as described previously (Travagli et al., 1991; Browning et al., 1999). In brief, the rat was anesthetized deeply with halothane (abolition of the foot-pinch withdrawal reflex) before being killed by severing the major blood vessels in the chest. The brainstem was removed and placed into chilled oxygenated Krebs' solution (see below for composition). A vibratome was used to cut four to five coronal slices (300 $\mu \mathrm{m}$ thick) containing the DMV; the slices were incubated at $32^{\circ} \mathrm{C}$ for at least $60 \mathrm{~min}$ in oxygenated Krebs' solution before use. A single slice was transferred to a custom-made perfusion chamber (volume, $500 \mu \mathrm{l}$ ), kept in place with a nylon mesh, and maintained at $35^{\circ} \mathrm{C}$ by perfusion with warmed Krebs' solution at a rate of $2.5-3.0 \mathrm{ml} / \mathrm{min}$.

A Nikon (Tokyo, Japan) E600FN microscope equipped with tetramethylrhodamine isothiocyanate epifluorescence filters was used to identify retrogradely labeled DMV neurons. Electrophysiological recordings were made under brightfield illumination using differential interference contrast (Nomarski) optics once the identity of a labeled neuron was confirmed.

Whole-cell patch-clamp recordings were made with patch pipettes of resistance 3-7 M $\Omega$ when filled with a potassium gluconate intracellular solution (see below for solution composition). A single-electrode voltage-clamp amplifier was used (Axopatch 1D; Axon Instruments, Union City, CA); data were acquired at $100 \mathrm{kHz}$, filtered at $2 \mathrm{kHz}$, digitized via a Digidata 1320 interface (Axon Instruments), stored, and analyzed on a personal computer using pClamp8 software (Axon Instruments). Only those recordings with a series resistance $<15 \mathrm{M} \Omega$ were accepted.

Drugs were applied to the bath at concentrations shown previously to be effective via a series of manually operated values. Neurons were allowed to recover fully between additions of agonists (minimum washout period of $10 \mathrm{~min}$ ). Antagonists were superfused for at least $5 \mathrm{~min}$ before reapplication of the agonist. Each neuron served as its own control when assessing the effects of antagonists (i.e., in each neuron, the effect of any drug was assessed before and after antagonist using the Student's $t$ test with significance set as $p<0.05$. A $\pm 10 \%$ variation of the amplitude of evoked currents was arbitrarily taken as indicative of an effect. Results are expressed as mean \pm SEM.

When recording spontaneous currents, the intracellular solution contained $\mathrm{KCl}$ instead of $\mathrm{K}$-gluconate, and the perfusion solution contained $1 \mathrm{~mm}$ kynurenic acid. Spontaneous currents were identified as GABAergic IPSCs, because they were abolished by perfusion with $30 \mu \mathrm{m}$ bicuculline (data not shown). Data were analyzed with the Mini Analysis program (Synaptosoft, Leonia, NJ).

Electrical stimulation. Synaptic currents were evoked using tungsten bipolar stimulating electrodes (World Precision Instruments, Sarasota, FL) placed in the centralis or medialis subnuclei of the NTS. Pairs of stimuli $(0.05-1.0 \mathrm{msec}, 10-500 \mu \mathrm{A}, 100-400 \mathrm{msec}$ apart) were applied every $20 \mathrm{sec}$ to evoke submaximal IPSCs or EPSCs. When IPSCs were studied, the Krebs' solution contained $1 \mathrm{~mm}$ kynurenic acid. Recordings were conducted at $-50 \mathrm{mV}$ (IPSCs) or at $-60 \mathrm{mV}$ (EPSCs).

Immunohistochemistry. Rats $(n=14)$ were injected with fluorogold $(20 \mu \mathrm{g} / 1 \mathrm{ml}$ saline, i.p., per rat; Fluorochrome, Denver, CO) to label vagal preganglionic neurons innervating the subdiaphragmatic viscera, thus allowing delineation of the boundaries of the DMV (Fox and Powley, 1985; Zheng et al., 1999; Guo et al., 2001). Three days later, the rats were anesthetized, the brainstem was extracted as described above, and 200 $\mu \mathrm{m}$ thick slices were allowed to recover for $90 \mathrm{~min}$ in oxygenated Krebs' at $32^{\circ} \mathrm{C}$. Four to six brainstem slices from each of the individual rats were separated into the following groups, so that each animal provided slices to two different groups, and each group comprised two or three slices from four different animals: group 1, control (incubation in Krebs' solution for $60 \mathrm{~min}$ at $35^{\circ} \mathrm{C}$ ); group 2, control (incubation in Krebs' solution for $120 \mathrm{~min}$ at $35^{\circ} \mathrm{C}$ ); group 3 , stimulation of cAMP (incubation in $10 \mu \mathrm{M}$ forskolin for $60 \mathrm{~min}$ at $35^{\circ} \mathrm{C}$ ); group 4 , stimulation of cAMP (incubation in $10 \mu \mathrm{M}$ forskolin for $60 \mathrm{~min}$ at $35^{\circ} \mathrm{C}$ and then washout with Krebs' for $60 \mathrm{~min}$ at $35^{\circ} \mathrm{C}$ ); group 5, stimulation of cAMP (incubation in $10 \mu \mathrm{M}$ forskolin for $60 \mathrm{~min}$ at $4^{\circ} \mathrm{C}$ ); group 6 , blockade of PKA (incubation in $1 \mu \mathrm{M} \mathrm{N}$-[2-( $p$-Bromocinnamyl-amino)ethyl]5-isoquinolinesulfonamide dihydrochloride (H89) for $60 \mathrm{~min}$ at $35^{\circ} \mathrm{C}$ and then $\mathrm{H} 89$ plus $10 \mu \mathrm{M}$ forskolin for $60 \mathrm{~min}$ at $35^{\circ} \mathrm{C}$ ); group 7, blockade of protein translocation (incubation with $5 \mu \mathrm{M}$ brefeldin A for $60 \mathrm{~min}$ at $35^{\circ} \mathrm{C}$ and then brefeldin A plus 10 $\mu \mathrm{M}$ forskolin for $60 \mathrm{~min}$ at $35^{\circ} \mathrm{C}$ ).

After the incubation, tissue slices were fixed by immersion into cold Zamboni's fixative and stored at $4^{\circ} \mathrm{C}$ overnight. The slices were subsequently rinsed in PBS (see below for composition) and transferred into PBS containing 20\% sucrose and stored for $3 \mathrm{~d}$ (with daily changes of the PBS-sucrose solution). Serial cryostat sections (5-7 $\mu \mathrm{m}$ thick) were cut using Bright cryostat (Huntington, UK), and these tissue sections were processed for double-labeling immunofluorescence using rabbit antisera directed against $\mu$-opioid receptor (MOR1; 1:1000 dilution) (Arvidsson et al., 1995) and mouse monoclonal antibodies against glutamic acid decarboxylase (GAD-6; 1:200 dilution; Developmental Studies Hybridoma Bank, maintained by the Department of Pharmacology and Molecular Sciences, Johns Hopkins University School of Medicine, Baltimore, $\mathrm{MD}$, and the Department of Biological Sciences, University of Iowa, Iowa City, IA, under contract N01-HD-6-2915 from National Institute of Child Health and Human Development) as described previously (Kalyuzhny and Wessendorf, 1998).

The diluent used for all antibodies was $0.1 \mathrm{~m}$ PBS, pH 7.4, containing $1 \%$ bovine serum albumin, $1 \%$ normal donkey serum, $0.3 \%$ Triton $\mathrm{X}-100$, and $0.01 \%$ sodium azide. Sections were incubated with primary antibodies overnight at $4^{\circ} \mathrm{C}$, washed in PBS (three times for 15 min each) at room temperature (RT), and incubated for $1 \mathrm{hr}$ at RT with secondary antibodies [donkey anti-rabbit conjugated with cyanine 3.18 (Сy3), 1:100, MOR1 staining; and donkey anti-mouse conjugated with fluorescein isothiocyanate (FITC), 1:100, GAD-6 staining].

Confocal microscopic images were collected by using an MRC 1024 confocal scanning laser microscope (Zeiss, Thornwood, NY) equipped with a $\mathrm{Kr} / \mathrm{Ar}$-ion laser. The microscope was equipped with filters for the 
selective visualization of $\mathrm{Cy} 3$ and FITC. Sections were mounted with a $\mathrm{PBS} /$ glycerol solution containing $0.1 \%$ phenylenediamine to reduce fading (Johnson and Nogueira-Araujo, 1981).

Quantitative analysis was conducted on two to three tissue sections (50-100 $\mu \mathrm{m}$ apart) per animal in each group to identify labeled terminals apposing DMV neurons. Profiles were defined as double labeled for MOR1 and GAD-6 if both labels appeared in profiles similar in size and geometry that overlap after merging of the images of MOR1 (red color) and GAD-6 (green color) resulting in yellow color. Profiles double labeled for MOR and GAD were counted manually on single optical layer sections by an investigator unaware of the treatment and expressed as MOR-GAD colocalized profiles in a $400 \times 600 \mu \mathrm{m}$ area (i.e., $0.24 \mathrm{~mm}^{2}$ ). MOR1 and GAD-67-positive profiles were considered apposing Fluorogold-labeled neurons if there was no perceivable distance between those profiles and the neuron itself.

In another set of experiments, we first assessed the presynaptic effects of met-enkephalin (ME) on the IPSC amplitude and then the recorded neuron was injected with neurobiotin to allow its identification within the slice before we conducted three-dimensional (3D) image reconstruction and qualitative analysis on the profiles colocalizing GAD and MOR apposing the identified cell. In total, 19 neurons from 7 rats were analyzed and divided into the following four groups: group 1, control (incubation in Krebs' solution, no pharmacological treatment; $n=4$ ); group 2 , the presynaptic effects of ME on the IPSCs amplitude were "uncovered" by forskolin $(n=4)$; group 3, the presynaptic effects of ME on the IPSCs amplitude were not uncovered by forskolin $(n=7)$; group 4 , the presynaptic effects of ME on the IPSC amplitude were uncovered by forskolin, but the slice was fixed in Zamboni's fixative $1 \mathrm{hr}$ later $(n=4)$.

After overnight fixation at $4^{\circ} \mathrm{C}$, the slice was washed repeatedly in PBS-Triton-X before incubation in streptavidin-Texas Red (1:100) to visualize the neurobiotin-filled neuron. The slice was then processed for double-labeling immunofluorescence for MOR and GAD as described above, using donkey anti-rabbit conjugated with Cy2 (1:400; MOR staining) and donkey anti-mouse Cy5 (1:400; GAD staining) as secondary antibodies. The sections were then washed with PBS (three times for $2 \mathrm{hr}$ each), mounted onto histological slides, cleared in alcohol and xylene, and coverslipped with DPX (Fluka, Ronkonkoma, NJ). Mounted tissues were allowed to dry overnight at room temperature and then examined using confocal microscopy.

Three sequential Z-stack series of images ( 40 images per stack gathered at $0.3 \mu \mathrm{m}$ steps) of the brainstem region containing the neurobiotinTexas Red-labeled cell and profiles labeled for GAD (Cy5) and MOR (Cy2) were collected using Bio-Rad MRC 1000 confocal scanning laser microscope equipped with Kr/Ar-ion laser (Bio-Rad, Richmond, CA). Note that we used Z-stack only for 3D volume reconstructions, but we did not collapse these Z-stacks, because merging different optical layer planes would produce artifact colocalization of immunoreactive profiles. The microscope was equipped with filters for the selective visualization of Texas Red, Cy2, and Cy5. Images were collected using $60 \times$ lens and a zoom of 2. Sequences of collected images were converted into merged 3D volumes using Volocity software (version 2.6.1; Improvision, Lexington, MA) provided by the Supercomputer Institute for Digital Simulation and Advanced Computation (University of Minnesota, Minneapolis, MN). For visualization purposes, merged image series were pseudocolored as follows: blue, neurobiotin-Texas Red-labeled cell; green, GAD-labeled profiles; red, MOR-labeled profiles. Digital images were manipulated using Adobe Photoshop CS software (Adobe Systems, San Jose, CA).

Drugs and solutions. Krebs' contained the following (in mM): $126 \mathrm{NaCl}$, $25 \mathrm{NaHCO}_{3}, 2.5 \mathrm{KCl}, 1.2 \mathrm{MgCl}_{2}, 2.4 \mathrm{CaCl}_{2}, 1.2 \mathrm{NaH}_{2} \mathrm{PO}_{4}$, and $11 \mathrm{dex}-$ trose maintained at $\mathrm{pH} 7.4$ by bubbling with $95 \% \mathrm{O}_{2} / 5 \% \mathrm{CO}_{2}$. Intracellular solution contained the following (in $\mathrm{mM}$ ): $128 \mathrm{~K}$-gluconate (or $\mathrm{KCl}$ ), $10 \mathrm{KCl}, 0.3 \mathrm{CaCl}_{2}, 1 \mathrm{MgCl}_{2}, 10$ HEPES, 1 EGTA, 2 ATP-Na, and $0.25 \mathrm{GTP}-\mathrm{Na}$, adjusted to $\mathrm{pH} 7.35$ with $\mathrm{KOH}$. Zamboni's fixative contained the following: $1.6 \%(\mathrm{w} / \mathrm{v})$ paraformaldehyde, $19 \mathrm{mM} \mathrm{KH}_{2} \mathrm{PO}_{4}$, and $100 \mathrm{mM} \mathrm{Na}_{2} \mathrm{HPO}_{4} \cdot 7 \mathrm{H}_{2} \mathrm{O}$ in $240 \mathrm{ml}$ of saturated picric acid, $1600 \mathrm{ml}$ of $\mathrm{H}_{2} \mathrm{O}$, adjusted to $\mathrm{pH} 7.4$ with $\mathrm{HCl}$. PBS contained the following (in $\mathrm{mm}$ ): $115 \mathrm{NaCl}, 75 \mathrm{Na}_{2} \mathrm{HPO}_{4} \cdot 7 \mathrm{H}_{2} \mathrm{O}, 7.5 \mathrm{KH}_{2} \mathrm{PO}_{4}$.

DiI was purchased from Molecular Probes (Eugene, OR). All secondary antibodies were obtained from Jackson ImmunoResearch (West
Grove, PA). MOR1 antiserum was a generous gift from Dr. Bob Elde (University of Minnesota, Minneapolis, MN). GAD-67 was produced by Developmental Studies Hybridoma Bank. Neurobiotin and streptavidin-Texas Red were purchased from Vector Laboratories (Burlingame, CA). All other chemicals were purchased from Sigma (St. Louis, MO).

Statistical analysis. Results are expressed as means \pm SEM. Intergroup comparisons were analyzed with one-way ANOVA followed by the conservative Bonferroni test for individual post hoc comparisons or Student's paired $t$ test. Significance was defined as $p<0.05$.

\section{Results}

Electrophysiological recordings were made from 117 gastricprojecting DMV neurons. Qualitative or quantitative variations in response to opioid receptor agonists or antagonists were not found with respect to the distinct gastric regions studied; therefore, the results were combined.

\section{Effects of opioid peptides on inhibitory synaptic transmission} The amplitude of the evoked IPSCs (eIPSC) averaged $172 \pm 9.9$ $\mathrm{pA}$ (range, $106-608 \mathrm{pA} ; n=70$ ) at the beginning of the experiments and remained stable throughout the course of the experiments.

Under control conditions, opioid peptides had no effect on the amplitude of eIPSCs. In fact, the amplitude of the eIPSC was $172 \pm 9.9 \mathrm{pA}$ in control and $170 \pm 9.9 \mathrm{pA}$ in the presence of 10 $\mu \mathrm{M}$ ME (i.e., $99 \pm 0.9 \%$ of control; $n=70 ; p>0.05$ ). Similarly, neither the $\mu$-opioid receptor-selective agonist $\mathrm{D}-\mathrm{Ala}^{2}-\mathrm{N}$-Me$\mathrm{Phe}^{4}$-Glycol${ }^{5}$-enkephalin (DAMGO; $1 \mu \mathrm{M} ; n=9$ ), the $\delta$-opioid receptor-selective agonist D-Pen-[D-Pen $\left.{ }^{2,5}\right]$-enkephalin (DPDPE; $1 \mu \mathrm{M} ; n=5$ ), nor the $\kappa$-receptor-selective agonist trans-3,4dichloro- $N$-methyl- $N$-[2-(1-pyrrolidinyl)-cyclohexyl]-benzeneacetamide methane sulfonate (U50,488) $(1 \mu \mathrm{M} ; n=5)$ altered the amplitude of eIPSCs $(99.6 \pm 1.0,99.4 \pm 4.3$, and $104.1 \pm 2.8 \%$ of control, respectively; $p>0.05$ in each instance).

\section{cAMP-dependent facilitation of opioid inhibitory effects}

After perfusion with the adenylate cyclase activator forskolin (10 $\mu \mathrm{M})$, subsequent reapplication of $\mathrm{ME}(10 \mu \mathrm{M})$ was able to inhibit eIPSC amplitude in 34 of 55 neurons (i.e., 62\%); the remaining neurons were unresponsive to ME. In detail, in 34 neurons, $\mathrm{ME}$ had no initial effect on eIPSC amplitude $(215 \pm 21 \mathrm{pA}$ in control compared with $211 \pm 22 \mathrm{pA}$ in the presence of ME; $n=34 ; p>$ $0.05)$. After 5 min exposure to forskolin, which itself had no effect on eIPSC amplitude $(212 \pm 23 \mathrm{pA}$ in control compared with $204 \pm 23 \mathrm{pA}$ in the presence of forskolin; $p>0.05$ ), reapplication of ME resulted in a $28 \pm 1.9 \%$ reduction in eIPSC amplitude $(220 \pm 23$ pA compared with $158 \pm 18 \mathrm{pA}$ in the presence of ME; $p<0.05$ ) (Fig. 1A).

In contrast, $5 \mathrm{~min}$ incubation with the inactive analog of forskolin, dideoxyforskolin $(10 \mu \mathrm{M})$, did not allow $\mathrm{ME}$ to inhibit eIPSCs. Specifically, five neurons, in which ME had no initial effect on eIPSC amplitude, were incubated with dideoxyforskolin, which itself had no effect on eIPSC amplitude. Reapplication of ME had no effect on eIPSC amplitude (105.0 $\pm 2.5 \%$ of control; $p>0.05$ ) (Fig. $1 B$ ). In four of five of these neurons, however, after 5 min perfusion with forskolin, subsequent superfusion with ME induced a $23.0 \pm 2.9 \%$ reduction in eIPSC amplitude $(p<0.05)$.

Incubation with the nonhydrolysable cAMP analog 8-bromocAMP ( $1 \mathrm{mM}$ ) also facilitated the inhibitory actions of ME in four of five (i.e., 80\%) neurons. After 5 min incubation with 8-bromocAMP, however, which itself had no effect on eIPSC amplitude, subsequent reapplication of ME resulted in a $30.2 \pm 6.5 \%$ inhibition in eIPSC amplitude $(p<0.05 ; n=4)$ (Fig. $1 B$ ). 
A

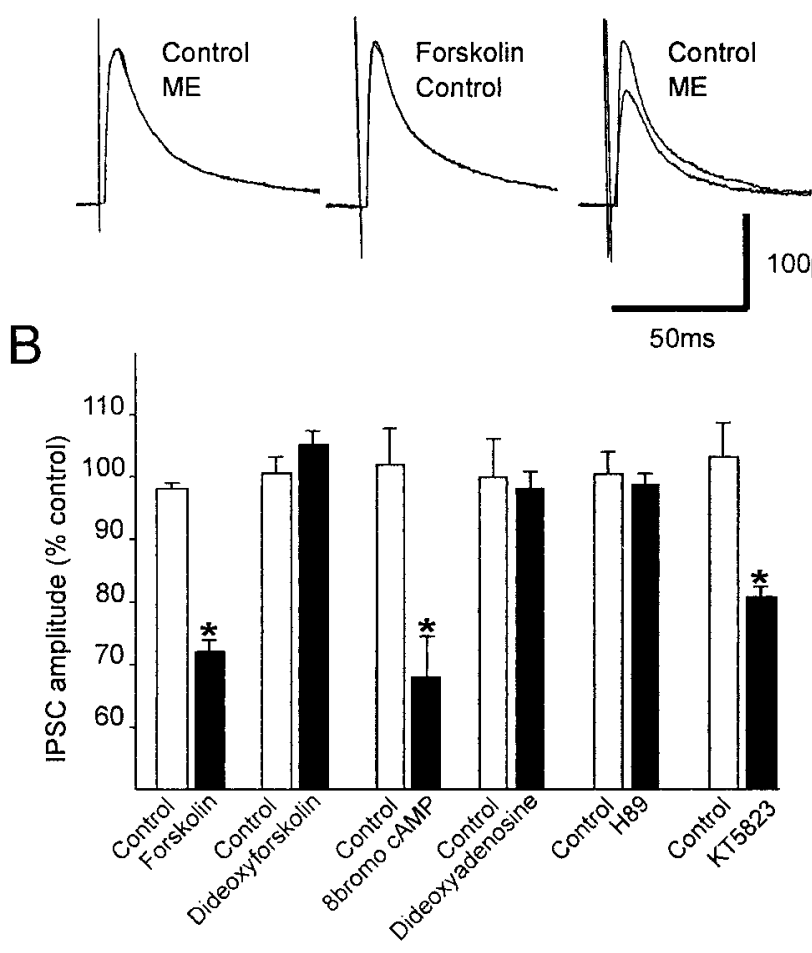

Figure 1. ME reduces the amplitude of elPSCs after activation of the CAMP-PKA pathway. $A$, Representative traces of elPSCs evoked in a gastric-projecting DMV neuron voltage clamped at $-50 \mathrm{mV}$. Perfusion with $10 \mu \mathrm{m}$ ME did not affect the amplitude of IPSCs evoked by electrical stimulation of the NTS (left panel). After 5 min perfusion with $10 \mu \mathrm{m}$ forskolin (center panel), perfusion with $10 \mu \mathrm{M}$ ME reduces the amplitude of the elPSCs. HP, $-50 \mathrm{mV}$. Each trace represents the average of three elPSCs evoked 20 sec apart. B, Histogram summarizing the involvement of the CAMP-PKA pathway in the uncovering of opioid receptors within the rat DVC. For each drug tested, the white bar represents the effects of ME $(10 \mu \mathrm{M})$ on elPSCs under control conditions; the black bar represents the effects of ME (10 $\mu \mathrm{M})$ after the drug treatment indicated. ${ }^{*} p<0.05$ vs control.

In contrast, the adenylate cyclase inhibitor, dideoxyadenosine $(10 \mu \mathrm{M})$, prevented forskolin from facilitating the inhibitory actions of $\mathrm{ME}$ in all neurons tested. Specifically, in four neurons, dideoxyadenosine was superfused for $5 \mathrm{~min}(99.1 \pm 9.8 \%$ of control; $p>$ 0.05 ) before the addition of forskolin. After subsequent washout, reapplication of ME did not induce any reduction in eIPSC amplitude $(98.0 \pm 2.8 \%$ of control; $p>0.05)$ (Fig. $1 B)$.

Application of the PKA inhibitor H89 $(1 \mu \mathrm{M})$, but not the protein kinase $\mathrm{G}(\mathrm{PKG})$ inhibitor KT5823 (1 $\mu \mathrm{M})$, prevented forskolin from facilitating the inhibitory actions of ME on eIPSC amplitude. In detail, in five neurons, H89 was superfused for 5 min before and during application of forskolin; the PKA inhibitor itself had no effect on eIPSC amplitude. Subsequent reapplication of ME had no effect on eIPSC amplitude of any of the five neurons $(98.6 \pm 1.9 \%$ of control; $p>0.05)$ (Fig. $1 B$ ). In contrast, an additional five neurons were exposed to KT5823 before and during application of forskolin. The PKG inhibitor itself had no effect on eIPSC amplitude (93.5 $\pm 8.8 \%$ of control; $p>0.05$ ). Subsequent reapplication of ME resulted in a $20.0 \pm 1.5 \%$ reduction in eIPSC amplitude $(p<0.05 ; p>0.05$ compared with the inhibition induced by forskolin in the absence of KT5823) (Fig. 1B).

Application of the adenosine receptor antagonist 8-cyclopentyl-1,3-dipropylxantine (DCPCX) did not alter the inhibition of the IPSCs induced by ME after forskolin pretreat-
A

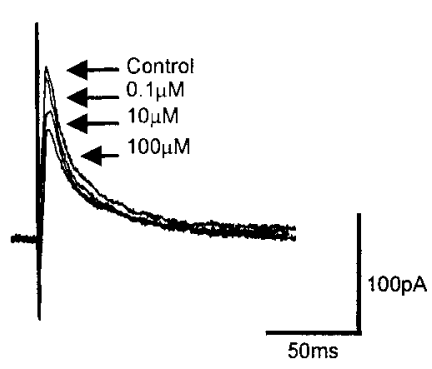

B

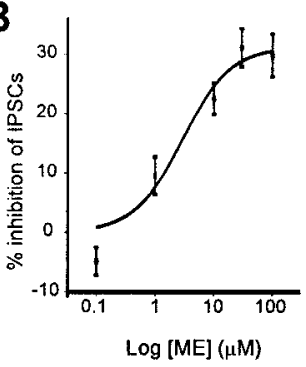

Figure 2. The inhibitory actions of ME are concentration dependent. $A$, Representative traces of elPSCs evoked in a gastric-projecting DMV neuron voltage clamped at $-50 \mathrm{mV}$. Initially, ME (10 $\mu \mathrm{m})$ had no effect on elPSC amplitude (data not shown). After perfusion with 10 $\mu \mathrm{m}$ forskolin, reapplication of ME induced a concentration-dependent inhibition in elPSC amplitude. Traces are the average of a minimum of three evoked currents. $B$, Concentrationresponse curve illustrating the concentration dependency of the ME-induced inhibition of evoked IPSC amplitude after stimulation with forskolin.

ment. In detail, three neurons in which $\mathrm{ME}(10 \mu \mathrm{M})$ initially had no effect on evoked IPSC amplitude $(103 \pm 6.8 \%$ of control; $p>$ $0.05)$ but inhibited IPSC amplitude after application of forskolin $(70 \pm 3.4 \%$ of control IPSC amplitude; $p<0.05)$ were incubated with $30 \mathrm{nM}$ DCPCX, which itself had no effect on the amplitude of the eIPSC (i.e., $108 \pm 8.9 \%$ of control; $p>0.05$ ). In the presence of DCPCX, ME reduced the amplitude of the eIPSC to $65 \pm 1.0 \%$ of control ( $p>0.05$ compared with inhibition in the absence of DCPCX; data not shown).

Finally, incubation with thyrotropin releasing hormone (TRH; $1-10 \mu \mathrm{M}$ ) also facilitated the inhibitory actions of ME in five of five neurons. After 5 min incubation with TRH, which itself had no effect on eIPSC amplitude, subsequent reapplication of ME resulted in a $24 \pm 2.2 \%$ inhibition in eIPSC amplitude $(p<0.05 ; n=5)$. Similar to TRH, pretreatment with cholecystokinin (CCK-8; $100 \mathrm{nM})$, which did not have any effects on eIPSC amplitude, reduced the amplitude of eIPSC in neurons by $22 \pm 2.6 \%$ of control $(p<0.05 ; n=5)$, otherwise unresponsive to perfusion with ME.

The ME-induced inhibition of eIPSC amplitude after stimulation of the CAMP-PKA pathway was concentration dependent (Fig. 2). Specifically, in 10 neurons in which ME (10 $\mu \mathrm{M})$ had no initial effect on eIPSC amplitude, after incubation with forskolin, reapplication of $10 \mu \mathrm{M} \mathrm{ME}$ induced a $22.5 \pm 2.6 \%$ reduction in eIPSC amplitude $(p<0.05)$. Because the time course of opioid receptor insertion was found to be stable for $\sim 30 \mathrm{~min}$ (see below), after washout and recovery of the eIPSC amplitude to control levels, it was possible to test up to two additional concentrations of ME on any one neuron. The maximum ME-induced inhibition occurred in response to application of $30 \mu \mathrm{M} \mathrm{ME} \mathrm{(31.1} \pm$ $3.2 \%$ reduction; $p<0.05)$; the threshold for the ME response was $\sim 1 \mu \mathrm{M}$, and the estimated $\mathrm{IC}_{50}$ value was $\sim 3 \mu \mathrm{M}$ (Fig. $2 B$ ).

This uncovering of functional opioid receptors cannot be attributed to repeated applications of opioid peptides themselves. In neurons where ME had no effect on eIPSC amplitude, repeated applications of ME did not result in any subsequent facilitation (eIPSC amplitude was $97.8 \pm 3.0 \%$ of control after the first application of $\mathrm{ME}$, and $97.8 \pm 1.4 \%$ of control after the second application; $n=5 ; p>0.05)$. Similarly, the lack of response to ME in untreated cells cannot be attributed to subthreshold responses to ME. In fact, to foster the ability to see presynaptic inhibition in eight cells, the extracellular calcium concentration was reduced from 2.4 to $1.45 \mathrm{~mm}$; perfusion with $\mathrm{ME}$ did not reduce the amplitude of the eIPSC $(107 \pm 6.1 \%$ of control; 


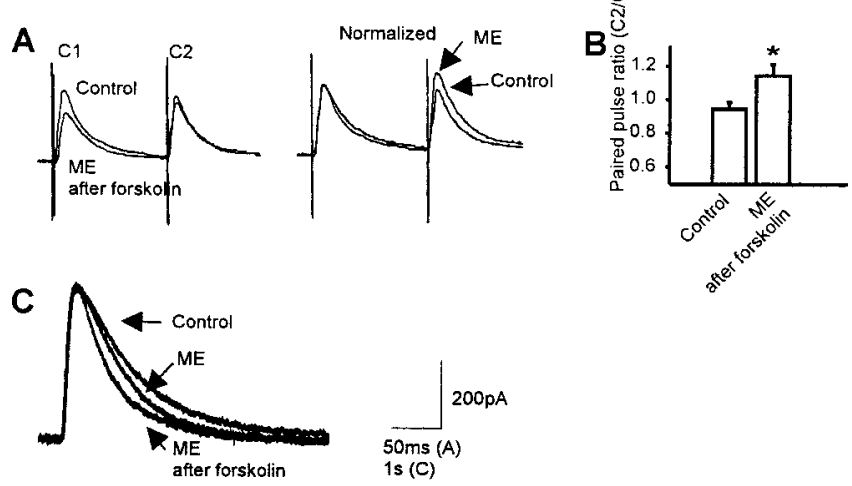

Figure 3. Opioid peptides inhibit IPSC amplitude via actions at presynaptic receptors. $A$, Representative traces of IPSCs evoked by paired current stimuli 100 msec apart. Initially, ME (10 $\mu \mathrm{M}$ ) had no effect on IPS (amplitude (data not shown). After superfusion with forskolin (10 $\mu \mathrm{M}$; data not shown), perfusion with ME (10 $\mu \mathrm{M})$ inhibited elPSC amplitude (left traces). The alteration in the paired-pulse ratio can be observed more readily after normalization of the ME following the forskolin trace to control amplitude. $B$, Paired-pulse ratio for the traces in which there was an increase in the amplitude after forskolin treatment as with the traces in $A$. The paired-pulse ratio compares the amplitude of the second current (C2) to that of the first current (C1). C, Muscimol $(100 \mu \mathrm{m})$ was pressure ejected in the vicinity $(10-20 \mu \mathrm{m})$ of the recorded DMV neuron. Neither the amplitude nor the duration of the muscimol-induced outward currents were altered by superfusion with $\mathrm{ME}(10 \mu \mathrm{M})$, forskolin $(10 \mu \mathrm{M})$, or repeated application of ME $(10 \mu \mathrm{M}) .{ }^{*} p<0.05$ vs control.

$p>0.05)$. In five of these cells, we tested the effects of ME after forskolin treatment; in four of five of these cells, the inhibition of eIPSC amplitude induced by perfusion with $10 \mu \mathrm{M} \mathrm{ME}$ was $73 \pm$ $4.5 \%$ of control ( $p>0.05$ compared with ME in Krebs' with 2.4 mM extracellular calcium).

Opioids act presynaptically to inhibit eIPSC amplitude

In neurons where forskolin induced the ability of ME to decrease eIPSC amplitude, the ratio of IPSCs evoked by two identical electrical pulses delivered 100-400 msec apart increased from a control value of $0.96 \pm 4.1$ to $1.16 \pm 6.9$ (Fig. $3 A, B$ ). Such an alteration in the paired-pulse ratio is suggestive of a presynaptic site of action. The presynaptic nature of ME effects was suggested further by using the $\mathrm{GABA}_{\mathrm{A}}$ agonist, muscimol (100 $\left.\mu \mathrm{M}\right)$, applied by pressure ejection to evoke an outward current $(339 \pm 69 \mathrm{pA} ; n=$ $6)$. The amplitude of the muscimol-induced current was not affected by superfusion with $10 \mu \mathrm{M} \mathrm{ME}(100.3 \pm 2.0 \%$ of control; $n=6 ; p>0.05)$, by exposure to $10 \mu \mathrm{M}$ forskolin (105.4 $\pm 19.8 \%$ of control; $n=6 ; p>0.05)$, or by reapplication of ME (97.6 \pm $2.1 \%$ of control; $n=6 ; p>0.05$ ) (Fig. $3 C$ ). Finally, perfusion with $10 \mu \mathrm{M}$ forskolin reduced the interevent interval of spontaneous IPSCs from $1083.8 \pm 248.9 \mathrm{msec}$ in control to $519.7 \pm$ $161.5 \mathrm{msec}$ in forskolin $(n=6 ; p<0.05)$, leaving the amplitude of the events unaltered $(38.3 \pm 6.7 \mathrm{pA}$ in control and $43.1 \pm 4.7$ $\mathrm{pA}$ in forskolin; $n=6 ; p>0.05)$. After the addition of ME, the amplitude of the spontaneous IPSCs was unaffected (44 \pm 7.9 $\mathrm{pA} ; p>0.05$ vs forskolin alone), but the interevent interval was increased $(1574.5 \pm 417.4 \mathrm{msec} ; p<0.05)$. A representative example is depicted in Figure 4.

The inhibition of evoked IPSC amplitude occurs via actions of $\boldsymbol{\mu}$-opioid receptors only

In all responsive neurons tested, the actions of $\mathrm{ME}$ to inhibit eIPSC amplitude were abolished by superfusion with the $\mu$-opioid receptor-selective antagonist D-Phe-Cys-Tyr-D-TrpOrn-Thr-Pen-Thr- $\mathrm{NH}_{2}$ (CTOP; $\left.1 \mu \mathrm{M}\right)$. In detail, after incuba-

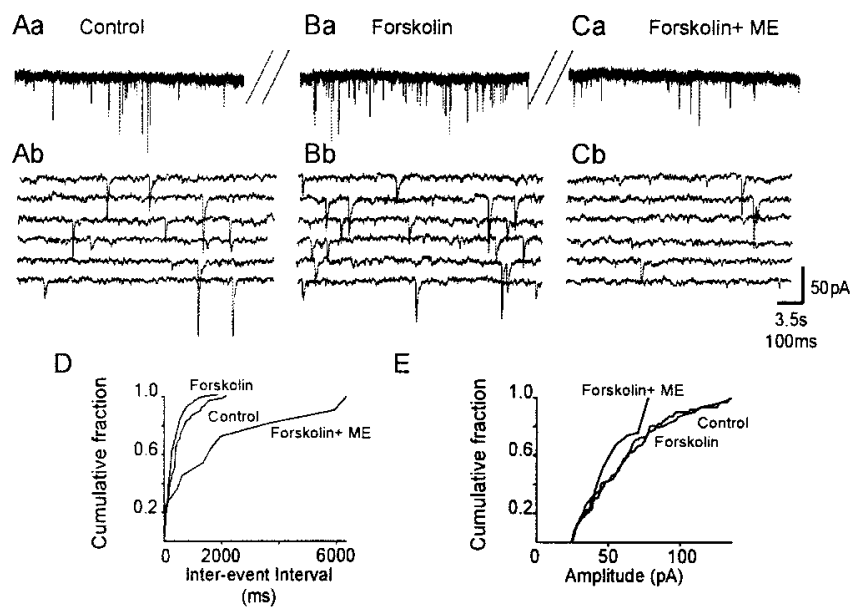

Figure 4. Opioid peptides decrease the frequency but not the amplitude of spontaneous IPSCs. Top and middle panels, Representative traces showing spontaneous IPSCs in control conditions; perfusion with $10 \mu \mathrm{m}$ forskolin increased the frequency of spontaneous IPSCS. $A-C$, After the addition of $10 \mu \mathrm{M} M E$, the frequency of spontaneous IPSCs decreased $(A, B, C a$, compressed scale; $A, B, C b$, expanded details). $D, E$, Bottom panels, Computer-generated graphics from the same neuron as above showing that forskolin and forskolin plus ME altered the frequency $(D)$ but not the amplitude $(E)$ of spontaneous IPSCs. Holding potential, $-50 \mathrm{mV}$. The breaks in record indicate a 5 min period between traces.

tion with forskolin $(10 \mu \mathrm{M})$, application of $\mathrm{ME}(10 \mu \mathrm{M})$ induced a $29.4 \pm 6.2 \%$ inhibition in eIPSC amplitude $(n=5 ; p<0.05)$. After recovery of eIPSC amplitude to baseline values, pretreatment with CTOP, which itself had no effect on eIPSC amplitude (104.2 $\pm 10.2 \%$ of control; $p>0.05)$, attenuated the ME-induced inhibition to $1.1 \pm 4.1 \%(p<0.05$; data not shown $)$.

Furthermore, in nine neurons, the $\mu$-opioid receptorselective agonist DAMGO $(1 \mu \mathrm{M})$ initially had no effect on eIPSC amplitude $(99.6 \pm 1.9 \%$ of control; $p>0.05)$. After perfusion with forskolin $(10 \mu \mathrm{M})$, however, reapplication of DAMGO resulted in a $24.9 \pm 3.4 \%$ decrease in eIPSC amplitude $(p<0.05)$. In five of five of these neurons, pretreatment with $1 \mu \mathrm{M} \mathrm{CTOP}$ attenuated the DAMGO-induced inhibition from $21.1 \pm 3.1 \%$ inhibition to $6.8 \pm 2.1 \%(p<0.05$; data not shown $)$. In contrast, neither DPDPE ( $1 \mu \mathrm{M} ; n=3)$ nor U50,488 ( $1 \mu \mathrm{M} ; n=2)$ had any effect on eIPSC amplitude $(99.4 \pm 4.3 \%$ of control and $104.0 \pm$ $2.8 \%$ of control, respectively; $p>0.05)$, even after perfusion with forskolin $(10 \mu \mathrm{M} ; 99.99 \pm 3.8$ and $99.4 \pm 3.0 \%$, respectively; $p>$ 0.05; data not shown).

\section{Time course of presynaptic opioid receptor recovery}

\section{from insertion}

The time course of opioid receptor recovery from insertion was assessed in eight neurons. After perfusion with forskolin $(10 \mu \mathrm{M})$, 5 min after forskolin was washed out, application of ME induced a $32.2 \pm 3.2 \%$ inhibition in eIPSC amplitude. ME was then reapplied again at various subsequent time points; the magnitude of the ME-induced inhibition remained constant for up to $30 \mathrm{~min}$ after forskolin application, declining gradually thereafter such that $60 \mathrm{~min}$ after forskolin application, ME no longer induced an inhibition in evoked IPSC amplitude (Fig. 5).

Forskolin does not uncover opioid receptors on glutamatergic nerve terminals

As demonstrated previously (Browning et al., 2002), activation of presynaptic $\mu$-opioid receptors inhibits glutamatergic synaptic transmission in all neurons studied $(n=21)$. Perfusion with ME 


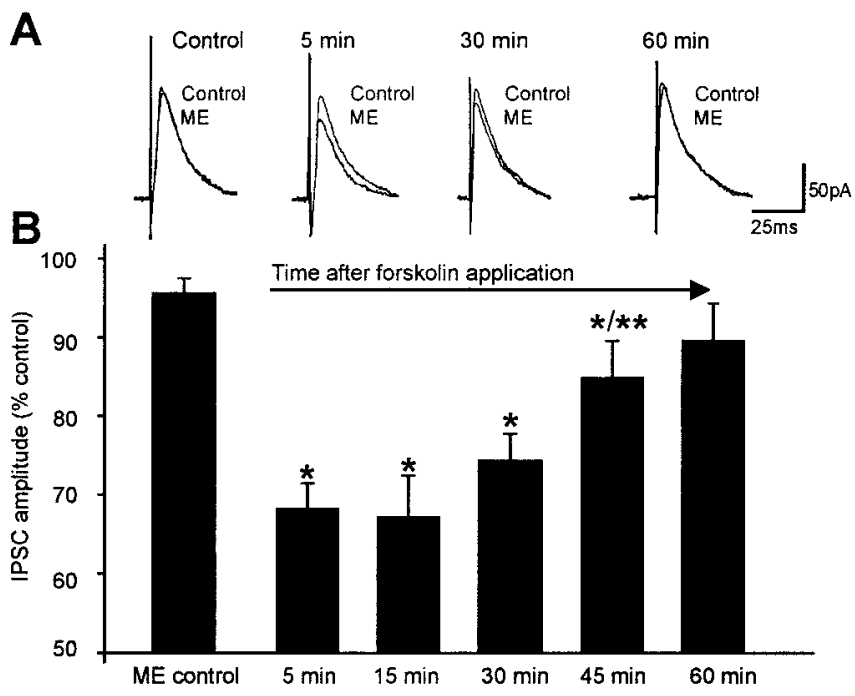

Figure 5. Time course of $\mu$-opioid receptor insertion. $A, B$, Under control conditions, ME (10 $\mu \mathrm{M}$ ) had no effect on elPSCs (traces in $A$; histogram in $B$ ). After forskolin $(10 \mu \mathrm{m})$, repeated application of ME induced an inhibition in elPSC amplitude that was stable for $\sim 30 \mathrm{~min}$. By 45 min, ME was still able to induce an inhibition in elPSC amplitude, albeit smaller than that induced at $5 \mathrm{~min}$. By $60 \mathrm{~min}$ after forskolin application, ME was once again unable to inhibit elPSC amplitude. ${ }^{*} p<0.05$ versus control; ${ }^{* *} p<0.05$ versus 5 min.

$(1 \mu \mathrm{M})$ reduced the amplitude of evoked EPSCs from $320 \pm 49$ to $179 \pm 45$ pA (i.e., a $47 \pm 9.0 \%$ inhibition). After application of forskolin, the inhibition induced by subsequent reapplication of ME was unchanged at $39 \pm 9.0 \%(391 \pm 63 \mathrm{pA}$ reduced to $248 \pm$ $65 \mathrm{pA} ; p>0.05$ compared with the first application; data not shown).

\section{Immunohistochemistry}

As reported previously (Browning et al., 2002) in control conditions (i.e., slices incubated for 60 or $120 \mathrm{~min}$ in Krebs' at $35^{\circ} \mathrm{C}$ ), very few, if any, instances of profiles double labeled for MOR1 and GAD apposing fluorogold-positive DMV neurons were observed ( $45 \pm 14$ profiles per $\left.0.24 \mathrm{~mm}^{2} ; n=4\right)$. When pretreated with $10 \mu \mathrm{M}$ forskolin, however, the majority of fluorogoldpositive cells in the DMV revealed appositions of profiles with colocalized MOR1 and GAD-IR (555 \pm 111 profiles per 0.24 $\left.\mathrm{mm}^{2} ; n=4\right)$. As with the electrophysiology results, if the slices were preincubated with $\mathrm{H} 89$ before the addition of forskolin, or if a 60 min washout was conducted after forskolin incubation, the colocalization of MOR and GAD-IR in profiles apposing fluorogold-labeled somata was greatly reduced $46 \pm 16$ and $35 \pm 13$ profiles per $0.24 \mathrm{~mm}^{2}$, respectively; $n=4$ for both groups) (Fig. $6 A-C$; data are summarized in $D$ ).

In another set of experiments, the presynaptic effects of ME on the IPSC amplitude were assessed and then the recorded neuron was injected with neurobiotin before conducting a highresolution qualitative analysis of GAD-MOR immunohistochemistry. In the control group (i.e., neurons that did not undergo any pharmacological treatment), profiles colocalizing GAD and MOR were rarely observed apposed to the identified neurons (group $1 ; n=7$ ) (Fig. 7A). Similarly, GAD and MOR colocalized profiles were rarely observed apposed to the identified neuron in groups where forskolin did not uncover presynaptic effects of ME (group 2; $n=4$ ) or where forskolin did uncover presynaptic effects of ME, but the slices were allowed to recover for $60 \mathrm{~min}$ before fixation (group 3; $n=4$ ). In the final group of neurons, however, where forskolin did uncover presyn-
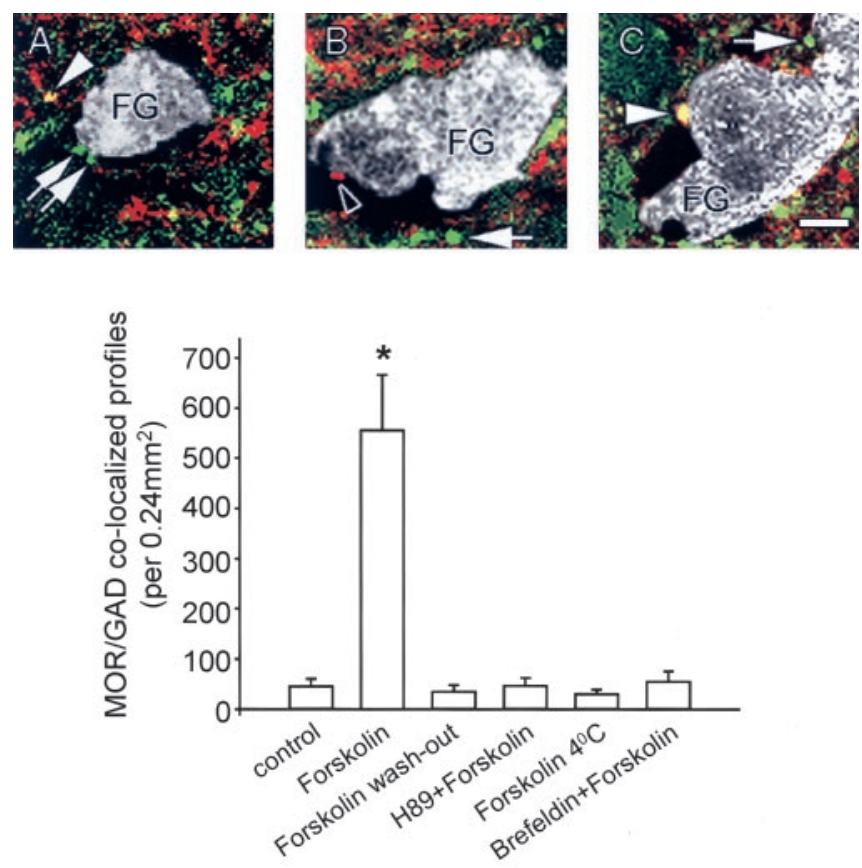

Figure 6. Elevation of cAMP levels induced insertion of $\mu$-opioid receptors of GABAergic profiles. Images represent single optical layer sections (see Materials and Methods). Red, MORIR; green, GAD-IR; white-gray, fluorogold (FG); yellow, profiles double labeled for MOR and GAD. A, High-magnification pseudocolor image illustrating an FG-positive DMV neuron that is apposed by GAD-IR profiles (arrows) but not by MOR-GAD double-labeled profile (filled arrowhead). $B, M O R-I R$ (open arrowhead) is present in a profile apposing one of the two adjacent FG-positive DMV neurons. A GAD-IR profile (filled arrow) is adjacent but not apposing the FG-positive cells. C, MOR-GAD double-labeled profiles (filled arrowhead) as well as by GAD-IR profiles (solid arrow) can be seen apposed to a group of FG-positive DMV neurons. Scale bar, 20 $\mu \mathrm{m}$. $D$, Histogram illustrating the summarized results of the immunohistochemical experiments. ${ }^{*} p<0.05$ vs control.

aptic effects of ME and the brainstem slice was fixed immediately, (group $4 ; n=4$ ), there was a dramatic increase in MOR-GAD colocalized profiles apposing the identified neurons (Fig. 7B).

\section{Blockade of protein translocation prevents the effects of forskolin}

In five of the six neurons tested, 10 min pretreatment with $5 \mu \mathrm{M}$ brefeldin A, a Golgi-disturbing agent (Law et al., 2000; Chaipatikul et al., 2003), followed by 5 min perfusion with brefeldin A and forskolin $(10 \mu \mathrm{M})$, failed to facilitate the ME-induced inhibition of eIPSC amplitude $(190 \pm 27.6 \mathrm{pA}$ in brefeldin A and $189 \pm$ $31.2 \mathrm{pA}$ in brefeldin A plus ME; $n=5 ; p>0.05$ ) (Fig. $8 A$ ). When GAD and MOR1 labeling was examined in slices preincubated in brefeldin A before the addition of forskolin, the number of profiles coexpressing GAD-IR and MOR-IR was significantly decreased when compared with slices incubated in forskolin alone $\left(54 \pm 21\right.$ vs $555 \pm 111$ profiles per $0.24 \mathrm{~mm}^{2}$ in brefeldin A plus forskolin and in forskolin alone, respectively) (Fig. 6D). Conversely, incubation with brefeldin A did not affect the inhibition of $1 \mu \mathrm{M} \mathrm{ME}$ on the eEPSC amplitude ( $48 \pm 6 \%$ of control in ME alone and $52 \pm$ $7 \%$ of control in brefeldin A plus ME; $n=3 ; p>0.05$ ) (Fig. $8 B$ ).

\section{Discussion}

In this study, we provided electrophysiological evidence showing that stimulation of the CAMP-PKA pathway regulates the insertion of presynaptic $\mu$-opioid receptors on GABAergic terminals within the rat DVC. The electrophysiological evidence is supported by immunohistochemical data, indicating that stimula- 

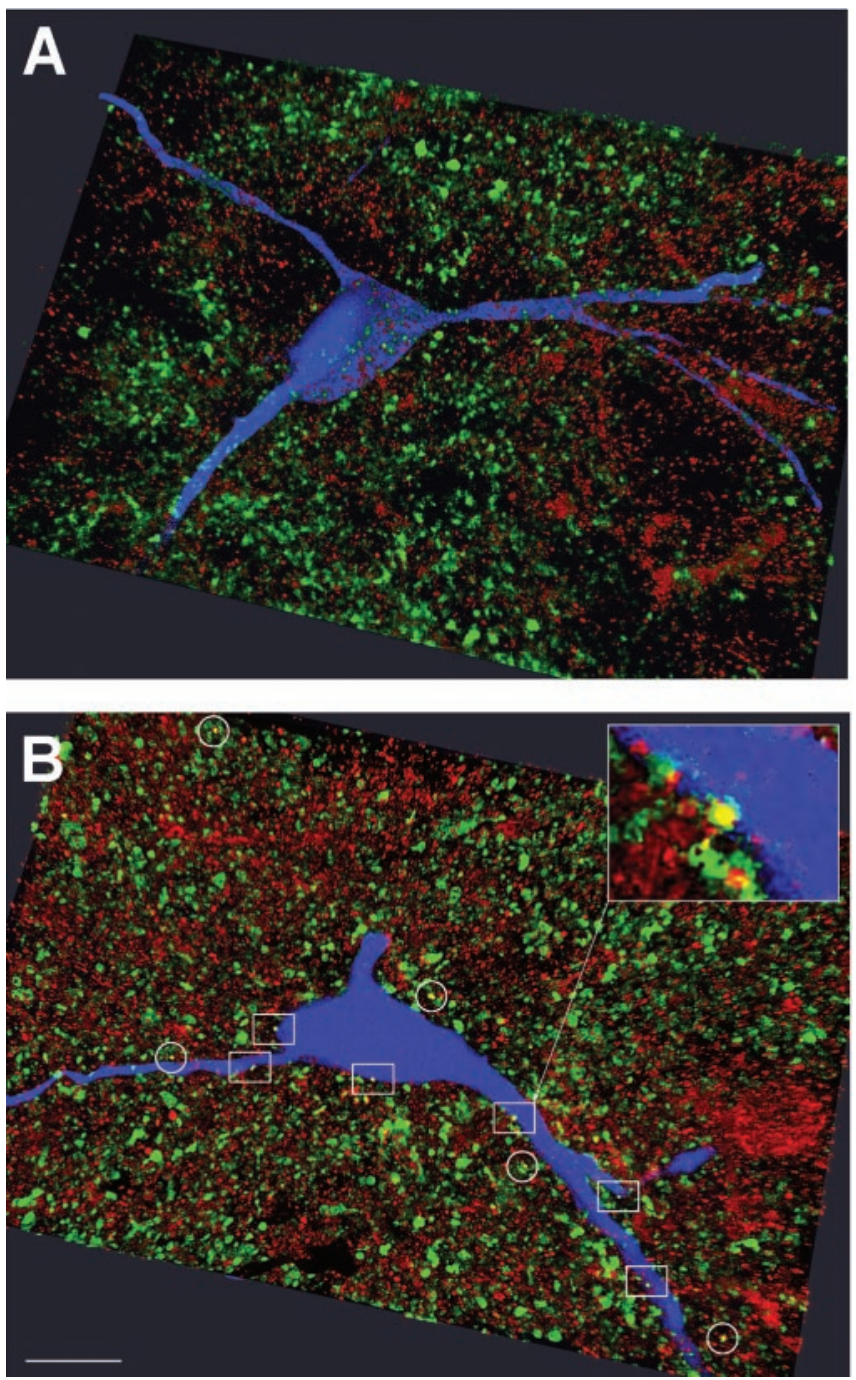

Figure 7. MOR and GAD colocalized profiles apposing electrophysiologically identified neurons. Images represent three-dimensional reconstructions from Z-stack image series (see Materials and Methods). Blue, Neurobiotin Texas Red-labeled cell; red, MOR-IR; green, GAD-IR; yellow, profiles double labeled for MOR and GAD. A, View of a neuron in control conditions (i.e., no pharmacological treatment). Note the absence of double-labeled profiles in the field of view. $B$, View of a neuron in which forskolin uncovered the presynaptic inhibition of IPSC amplitude by ME. Note the presence of both nonapposing (outlined by circles) and apposing (outlined by boxes) MOR-GAD double-labeled profiles onto the neurobiotin-labeled neuron. Top right, Note the exploded view of the area outlined by the highlighted box. Scale bar, $10 \mu \mathrm{m}$.

tion of the cAMP-PKA pathway induces the insertion of MOR on GAD-IR profiles apposed to DMV neurons. The results obtained with brefeldin A suggest that the appearance of $\mu$-opioid receptors on GABAergic profiles within the DVC is determined by receptor protein translocation triggered by the activity of the cAMP-PKA pathway. Because the predominant input from the NTS to the DMV is GABAergic, and the modulation by opioid peptides of excitatory inputs does not seem to be affected by the activity of the CAMP-PKA pathway, this would imply that the inhibitory actions of opioids on vagal brainstem circuits might be subject to exquisite regulation by the state of activation of GABAergic NTS neurons.

In agreement with our previous studies, the present data indicate that $\mu$-opioid receptors, but not $\delta$ - or $\kappa$-opioid receptors, are present within the rat DVC. The inhibition induced by ME after stimulation of cAMP levels was mimicked by the $\mu$-opioid
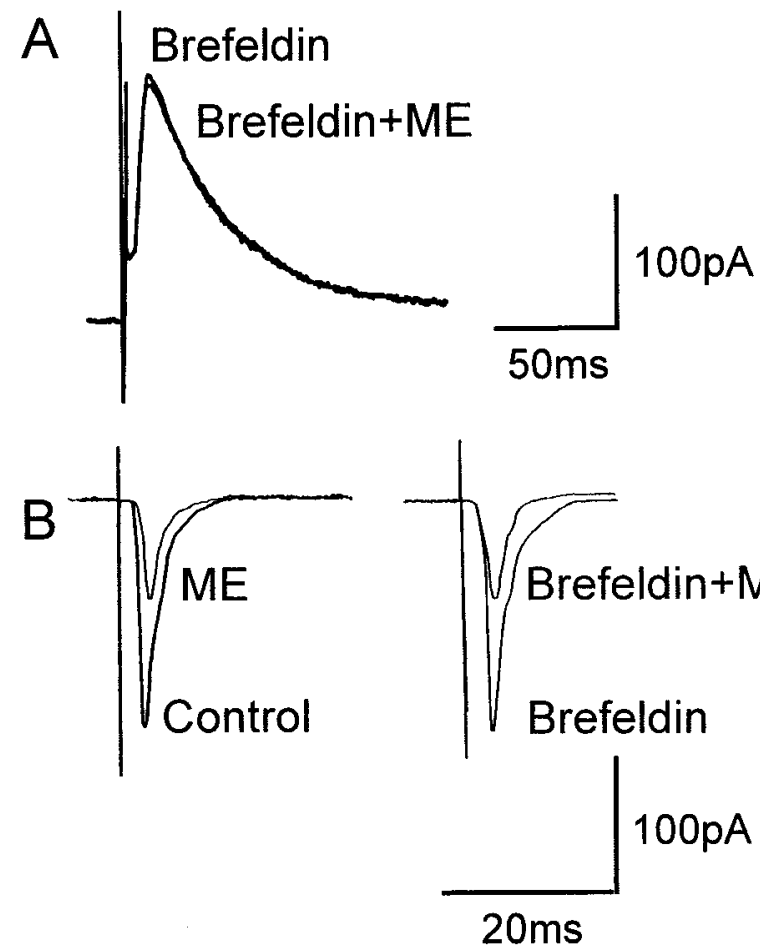

Figure 8. Inhibition of protein trafficking prevents the forskolin-induced colocalization of GAD and MOR1. A, Representative traces showing that preincubation with $5 \mu \mathrm{m}$ brefeldin $\mathrm{A}$ prevented the forskolin-induced ME-mediated attenuation of elPSCs (HP, $-50 \mathrm{mV}$; each elPSC is the average of three elPS(S). $B$, Representative traces showing that preincubation with $5 \mu \mathrm{M}$ brefeldin A did not affect the ME-mediated attenuation of eEPSC (HP, $-60 \mathrm{mV}$; each eEPSC is the average of three eEPS(s).

receptor-selective agonist DAMGO, and the effects of both ME and DAMGO were prevented by the $\mu$-opioid receptor-selective antagonist CTOP. Such receptors were located presynaptically on nerve terminals within the DVC. In contrast, neither the $\delta$-opioid receptor-selective agonist DPDPE nor the $\kappa$-opioid receptorselective agonist U50,488 had any effect on the amplitude of evoked IPSCs, even after stimulation of cAMP levels. Additional effects of $\mu$-opioids on glutamatergic synaptic transmission or on postsynaptic DMV neurons after stimulation of cAMP levels were not evident.

This insertion of presynaptic $\mu$-opioid receptors on GABAergic nerve terminals was linked to elevation of cAMP levels by the ability of forskolin, but not its inactive isomer dideoxyforskolin, to facilitate inhibitory actions of ME. Furthermore, the nonhydrolysable analog of cAMP, 8-bromo-cAMP, or neuromodulators such as TRH and CCK-8 known to increase cAMP (Passegue et al., 1995; Wank, 1998) were able to promote the presynaptic inhibitory actions of $\mathrm{ME}$, whereas the adenylate cyclase inhibitor, dideoxyadenosine, prevented the forskolin-stimulated MEinduced inhibition. The involvement of the cAMP-PKA system was further confirmed by the ability of the PKA inhibitor, H89, to prevent the ME-induced inhibition after forskolin stimulation. However, the PKG inhibitor KT5823 did not alter the effects of forskolin; this would suggest that within this system, little or no cross-talk exists between the PKA and PKG systems and that cAMP does not result in significant activation of PKG.

Opioid receptors are negatively coupled to adenylate cyclase; activation of $\mu$-opioid receptors therefore causes a decrease in cAMP levels. We postulated previously (Browning and Travagli, 2001) that in GABAergic nerve terminals, the basal levels of 
cAMP are too low for the activation of any receptors negatively coupled to adenylate cyclase (such as $\mu$-opioid receptors) to have any noticeable effect. Exposure to agents that raise cAMP levels (e.g., forskolin or 8-bromo-cAMP) would, however, allow such inhibitory actions of opioids to be observed.

However, the present data would argue against such a simplistic explanation. Our immunohistochemical evidence indicates that under basal conditions, $\mu$-opioid receptors are not present on GABAergic profiles; after stimulation of cAMP levels, however, MOR1-IR can be observed in cell processes and profiles apposed to DMV neurons. The rapid time course of $\mu$-opioid receptor insertion observed in our electrophysiological studies argues against cAMP-stimulated de novo receptor synthesis. Rather, we would suggest that stimulation of cAMP levels results in trafficking of stored $\mu$-opioid receptors to the cell membrane.

To our knowledge, this is the first demonstration of cAMPdependent insertion of opioid receptors into nerve terminal membranes. In fact, $\mu$-opioid receptors are most commonly described as being already present in nerve membranes under basal conditions and are internalized as part of the desensitization process (Sternini et al., 1996; Arttamangkul et al., 2000; Sternini, 2001; Haberstock-Debic et al., 2003). However, cAMPdependent receptor translocation has been demonstrated previously in both retinal ganglion cells and spinal motoneurons, where the neurotrophin receptor $\operatorname{TrkB}$ was inserted into the membrane within minutes of cAMP stimulation (Meyer-Franke et al., 1998). In a similar manner, Shuster et al. (1999) have shown that $\kappa$-opioid receptors were inserted into the membrane of magnocellular neurosecretory neurons after a physiological stimulus (salt loading). It is of interest to note that in their report, Shuster et al. (1999) showed that the $\kappa$-opioid receptors were present in the nerve terminal membrane for $60 \mathrm{~min}$ after the stimulus, a time course very similar to that observed in our present study for the insertion of $\mu$-opioid receptors. This type of insertion may be a generalized means by which neurotransmitter release can be regulated at the level of the presynaptic nerve terminal, although it appears to be a central rather than a peripheral phenomenon (Meyer-Franke et al., 1998).

Furthermore, it could be argued that by depending on activation of the CAMP-PKA pathway for insertion into the nerve terminal membrane, opioid receptors also provide a means by which that very second messenger signal can be attenuated or even terminated. Thus, activation of adenylate cyclase would result in an increase in cAMP levels; the consequent intracellular signaling cascade would, in turn, result in an insertion of $\mu$-opioid receptors onto the cell membrane. Ligand binding and activation of these $\mu$-opioid receptors would, in turn, decrease cAMP levels attenuating the second messenger signal. After the decrease in cAMP levels, $\mu$-opioid receptors would presumably be internalized away from the cell membrane.

The data presented in the present study underline the critical role that concomitant neurochemical signaling may exert on the role of opioid receptors within the rat brainstem. It would be expected that opioidergic systems would have little or no effect after inhibitory synaptic transmission within the DVC unless preceded or accompanied by a stimulation of the CAMP-PKA pathway (e.g., by neurotransmitters such as TRH or CCK). However, this may be a mechanism restricted to gastric parasympathetic motoneurons. A recent investigation demonstrated that $\mu$-opioid receptors inhibit GABAergic inputs to cardiac vagal motoneurons located in the nucleus ambiguus without the need for increasing the activity of the cAMP-PKA pathway (Venkatesan et al., 2002).
In summary, we have shown that in order for opioid peptides to inhibit GABAergic transmission in the DVC, it is necessary to induce the insertion of the receptor protein from intracellular stores inaccessible to the ligand unless the CAMP-PKA pathway is activated. Because we did not observe this type of regulation on glutamatergic terminals, we surmise that MOR1 might be expressed constitutively on glutamate terminals, which do not undergo state-dependent modulation. It is possible that the activitydependent control of GABAergic transmission by opioid peptides is part of a more widespread mechanism that controls the CNS output to the periphery and includes not only opioid peptides but also a larger array of neurotransmitters impinging on the NTS. This type of state-dependent modulatory control of the motor output might be an important manner through which neurotransmitters from higher centers regulate the response of the viscera, thus allowing the brainstem neuronal elements to act in harmony with neural systems that control behavioral and physiological homeostasis.

\section{References}

Aronin N, DiFiglia M (1992) The subcellular localization of the G-protein $\mathrm{Gi}$ alpha in the basal ganglia reveals its potential role in both signal transduction and vesicle trafficking. J Neurosci 12:3435-3444.

Arttamangkul S, Alvarez-Maubecin V, Thomas G, Williams JT, Grandy DK (2000) Binding and internalization of fluorescent opioid peptide conjugates in living cells. Mol Pharmacol 58:1570-1580.

Arvidsson U, Dado RJ, Chakrabarti S, Lee JH, Nakano AH, Dado RJ, Loh HH, Law PY, Wessendorf MW, Elde RJ (1995) Distribution and targeting of a mu-opioid receptor (MOR1) in brain and spinal cord. J Neurosci 15:3328-3341.

Browning KN, Travagli RA (2001) The peptide TRH uncovers the presence of presynaptic 5- $\mathrm{HT}_{1 \mathrm{~A}}$ receptors via activation of a second messenger pathway in the rat dorsal vagal complex. J Physiol (Lond) 531:425-435.

Browning KN, Renehan WE, Travagli RA (1999) Electrophysiological and morphological heterogeneity of rat dorsal vagal neurones which project to specific areas of the gastrointestinal tract. J Physiol (Lond) 517:521-532.

Browning KN, Kalyuzhny AE, Travagli RA (2002) Opioid peptides inhibit excitatory but not inhibitory synaptic transmission in the rat dorsal motor nucleus of the vagus. J Neurosci 22:2998-3004.

Browning KN, Kalyuzhny AE, Travagli RA (2003) State dependent activation of brainstem circuits by opioids. Paper presented at Thirty-Third Annual Neuroscience Meeting, New Orleans, LA, November.

Chaipatikul V, Erickson-Herbrandson LJ, Loh HH, Law PY (2003) Rescuing the traffic-deficient mutants of rat mu-opioid receptors with hydrophobic ligands. Mol Pharmacol 64:32-41.

Cheng PY, Swingos AL, Wang H, Clarke CL, Jenab S, Beczkowska IW, Inturrisi CE, Pickel VM (1995) Ultrastructural immunolabeling shows prominent presynaptic vesicular localization of delta-opioid receptor within both enkephalin and nonenkephalin-containing axon terminals in the superficial layers of the rat cervical spinal cord. J Neurosci 15:59765988.

Commons KG (2003) Translocation of presynaptic delta opioid receptors in the ventrolateral periaqueductal gray after swim stress. J Comp Neurol 464:197-207.

Commons KG, Aicher SA, Kow LM, Pfaff DW (2000) Presynaptic and postsynaptic relations of $\mathrm{m}$-opioid receptors to g-aminobutyric acidimmunoreactive and medullary-projecting periaqueductal gray neurons. J Comp Neurol 419:532-542.

Cushmann SW, Wardzala LJ (1980) Potential mechanism of insulin action on glucose transport in the isolated rat adipose cell. Apparent translocation of intracellular transport systems to the plasma membrane. J Biol Chem 255:4758-4762.

Drake CT, Patterson TA, Simmons ML, Chavkin C, Milner TA (1996) Kappa opioid receptor-like immunoreactivity in guinea pig brain: ultrastructural localization in presynaptic terminals in hippocampal formation. J Comp Neurol 370:377-395.

Fox EA, Powley TL (1985) Longitudinal columnar organization within the dorsal motor nucleus represents separate branches of the abdominal vagus. Brain Res 341:269-282. 
Guo JJ, Browning KN, Rogers RC, Travagli RA (2001) Catecholaminergic neurons in rat dorsal motor nucleus of vagus project selectively to gastric corpus. Am J Physiol Gastrointest Liver Physiol 280:G361-G367.

Haberstock-Debic H, Wein M, Barrot M, Colago EE, Rahman Z, Neve RL, Pickel VM, Nestler EJ, Von Zastrow M, Svingos AL (2003) Morphine acutely regulates opioid receptor trafficking selectively in dendrites of nucleus accumbens neurons. J Neurosci 23:4324-4332.

Johnson GD, Nogueira-Araujo GM (1981) A simple method of reducing the fading of immunofluorescence during microscopy. J Immunol Methods 43:349-350.

Kalyuzhny AE, Wessendorf MW (1998) Relationship of $\mu$ and $\delta$-opioid receptors to GABAergic neurons in the central nervous system, including antinociceptive brainstem circuits. J Comp Neurol 392:528-547.

Kim KA, Von Zastrow M (2003) Neurotrophin-regulated sorting of opioid receptors in the biosynthetic pathway of neurosecretory cells. J Neurosci 23:2075-2085.

Law PY, Erickson LJ, El Kouhen R, Dicker L, Solberg J, Wang W, Miller E, Burd AL, Loh HH (2000) Receptor density and recycling affect the rate of agonist-induced desensitization of mu-opioid receptor. Mol Pharmacol 58:388-398.

Lewis S, de Moura J (1984) Apical membrane area of rabbit urinary bladder increases by fusion of intracellular vescicles. J Membr Biol 82:123-136.

Meyer-Franke A, Wilkinson GA, Kruttgen A, Hu M, Munro E, Hanson MG, Reichart LF, Barres BA (1998) Depolarization and cAMP elevation rapidly recruit TrkB to the plasma membrane of CNS neurons. Neuron 21:681-693.

Passegue E, Richard JL, Boulla G, Gourdji D (1995) Multiple intracellular signallings are involved in thyrotropin-releasing hormone (TRH)induced c-fos and jun B mRNA levels in clonal prolactin cells. Mol Cell Endocrinol 107:29-40.
Shuster SJ, Riedl M, Li X, Vulchanova L, Elde R (1999) Stimulus-dependent translocation of kappa opioid receptors to the plasma membrane. J Neurosci 19:2658-2664.

Sternini C (2001) Receptors and transmission in the brain-gut axis: potential for novel therapies. III. Mu-opioid receptors in the enteric nervous system. Am J Physiol Gastrointest Liver Physiol 281:G8-G15.

Sternini C, Spann M, Anton B, Keith DE, Bunnett NW, Von Zastrow M, Evans C, Brecha NC (1996) Agonist-selective endocytosis of $\mu$ opioid receptor by neurons in vivo. Proc Natl Acad Sci USA 93:9241-9246.

Travagli RA, Rogers RC (2001) Receptors and transmission in the brain-gut axis: potential for novel therapies. V. Fast and slow extrinsic modulation of dorsal vagal complex circuits. Am J Physiol Gastrointest Liver Physiol 281:G595-G601.

Travagli RA, Gillis RA, Rossiter CD, Vicini S (1991) Glutamate and GABAmediated synaptic currents in neurons of the rat dorsal motor nucleus of the vagus. Am J Physiol 260:G531-G536.

Venkatesan P, Wang J, Evans C, Irnaten M, Mendelowitz D (2002) Endomorphin-2 inhibits GABAergic inputs to cardiac parasympathetic neurons in the nucleus ambiguus. Neuroscience 113:975-983.

Wank SA (1998) G-protein-coupled receptors in gastrointestinal physiology. I. CCK receptors: an exemplary family. Am J Physiol 274:G607-G613.

Zhang X, Bao L, Arvidsson U, Elde R, Hokfelt T (1998) Localization and regulation of the delta-opioid receptor in dorsal root ganglia and spinal cord of the rat and monkey: evidence of association with the membrane of large dense-core vescicles. Neuroscience 82:1225-1242.

Zheng ZL, Rogers RC, Travagli RA (1999) Selective gastric projections of nitric oxide synthase-containing vagal brainstem neurons. Neuroscience 90:685-694. 